\title{
Prokaryotic cell surface biopolymers: bioinformatic analysis
}

Shchyogolev S.Yu. ${ }^{1,2}$, Burygin G.L. ${ }^{1,3}$, Pyatibratov M.G. ${ }^{4}$

${ }^{1}$ Institute of Biochemistry and Physiology of Plants and Microorganisms, Russian Academy of Sciences, Saratov, Russia;

${ }^{2}$ Saratov National Research State University named after N.G. Chernyshevsky, Saratov, Russia; ${ }^{3}$ Saratov State Agrarian

University named after N.I. Vavilov, Saratov, Russia; ${ }^{4}$ Institute of Protein Research, Russian Academy of Sciences,

Pushchino, Russia

E-mail: shegolev_s@ibppm.ru

Key message. Using the example of a number of representatives of bacteria and archaea, the structure of their cell surface biopolymers is considered, taking into account post-translational modifications of proteins and contemporary views on the features of protein folding.

Keywords: bacteria, archaea, flagellins, archellins, bioinformatics

The experience of applying molecular modeling for studying the structure and post-translational modifications of flagellins, pilins, and archellins of a number of prokaryotes using the appropriate bioinformatic resources is discussed. We also used these results to optimize genetic engineering work on the modification of archellins for their use in creating nanomaterials with targeted properties. Given the intrinsically disordered protein regions found in silico, the role of contemporary views on the features of protein folding in the interpretation of the results obtained is noted. Taking into account some experimental data reported in the literature, possibilities and limitations of programs for predicting carbohydrate attachment sites for glycosylation of flagellins and pilins (in bacteria) and of archellins (in archaea) are evaluated. The probability of alternative folding, i.e. obtaining two protein models with significantly different 3D structures and functions (flagellin and S-layer protein) for a single amino acid sequence, is demonstrated using a set of tools for homologous and template modeling of protein structures (I-TASSER, SwissModel, Modeller) for bacteria of the genera Azospirillum, Niveispirillum, and Nitrospirillum. These proteins are annotated as "hypothetical proteins" in NCBI entries, with the N- and C-terminal domains pf00669 and pf00700 characteristic of flagellins in the UniProt entries. The fundamental possibility of the existence of proteins with drastically different 3D structures and with identical amino acid sequences has been demonstrated [1] by the example of experimental results collected in the PDB database of protein structures. From the PDB database, two most probable alternative templates (flagellin from Salmonella typhimurium, 1UCU, and the S-layer protein from Caulobacter crescentus, 5N8P) were selected by the I-TASSER program and used to build the alternative models. These models were also confirmed by us using the SwissModel and Modeller programs. This work was supported by the Russian Foundation for Basic Research (grant No. 19-04-00613 A).

\section{Биополимеры клеточной поверхности прокариотов: биоинформатический анализ} Щеголев С.Ю. ${ }^{1,2}$, Бурыгин Г.Л. ${ }^{1,3}$, Пятибратов М.Г. ${ }^{4}$

${ }^{1}$ Институт биохимии и физиологии растений и микроорганизмов Российской академии наук, Саратов, Россия; ${ }^{2}$ Саратовский национальный исследовательский государственный университет им. Н.Г. Чернышевского, Саратов, Россия; ${ }^{3}$ Саратовский государственный аграрный университет им. Н.И. Вавилова, Саратов, Россия; ${ }^{4}$ Институт белка Российской академии наук, Пущино, Россия

\begin{abstract}
Аннотация. На примере ряда представителей бактерий и архей рассматривается строение биополимеров их клеточной поверхности с учетом посттрансляционных модификаций белков и современных представлений об
\end{abstract} особенностях белкового фолдинга.

Ключевые слова: бактерии, археи, флагеллинь, археллинь, биоинформатика

Обсуждается опыт применения молекулярного моделирования в исследованиях структуры и посттрансляционных модификаций флагеллинов, пилинов и археллинов ряда прокариотов с использованием соответствующих биоинформатических ресурсов. Эти результаты были задействованы нами также в оптимизации генно-инженерных работ по модификации археллинов с целью создания на их основе наноматериалов с заданными свойствами. Отмечается роль современных представлений об особенностях белкового фолдинга в интерпретации получаемых результатов с учетом обнаруживаемых in silico областей внутренней структурной неупорядоченности белков. Принимая во внимание известные из литературы экспериментальные данные, мы оценивали возможности и ограничения программ для предсказания сайтов присоединения углеводов при гликозилировании флагеллинов и пилинов (бактерии) и археллинов (археи). С использованием набора средств гомологичного моделирования и моделирования по шаблону структур белков (I-TASSER, SwissModel, Modeller) для бактерий родов Azospirillum, Niveispirillum и Nitrospirillum продемонстрирована вероятность реализации альтернативного фолдинга - получения для одной аминокислотной последовательности двух моделей белков с существенно различающейся 3D-структурой и функцией (флагеллин и белок S-слоя). B записях $\mathrm{NCBI} э т и$ белки аннотированы как «hypothetical protein», с характерными для флагеллинов N- и С-концевыми доменами pf00669 и pf00700 в записях UniProt. Принципиальная возможность существования белков с радикально отличающейся 3D-структурой, чьи аминокислотные последовательности идентичны на 100\%, была показана в работе [1] на примере результатов экспериментов, аккумулированных в базе данных белковых структур PDB. Именно из базы данных PDB программой ITASSER были отобраны два наиболее вероятных альтернативных шаблона (флагеллин из Salmonella typhimurium, 1UCU, и белок S-слоя из Caulobacter crescentus, 5N8P), использованные программой I-TASSER для построения альтернативных моделей, подтвержденных нами дополнительно с применением программ SwissModel и Modeller.

Работа поддержана Российским фондом фундаментальных исследований (грант № 19-04-00613 А).

[1] Kosloff M., Kolodny R. Sequence-similar, structure-dissimilar protein pairs in the PDB. Proteins. - 2008. - Vol. 71, No. 2. - P. 891-902. 